\title{
PENINGKATAN KEMAMPUAN GURU DALAM MENYUSUN PERANGKAT PENILAIAN AFEKTIF MELALUI SUPERVISI TEKNIK OFFICE-CONFERENCE DI SMA NEGERI 1 PINANGSORI TAHUN PELAJARAN 2017/2018
}

\author{
Muhammad Ali \\ Kepala SMA Negeri 1 Pinangsori
}

\begin{abstract}
Abstrak
Tujuan penelitian ini adalah untuk mengetahui peningkatkan kemampuan guru dalam menyusun perangkat penilaian afektif melalui superfisi teknik Office-Conference. Penelitian tindakan sekolah ini dilakukan sebanyak 2 siklus yang masing-masing siklus terdiri dari 4 kegiatan, yaitu perencanaan (planning), pelaksanaan (acting), pengamatan (observing), dan refleksi (reflecting). Penelitian Tindakan ini dilaksanakan pada subyek penelitian yaitu sebanyak 13 orang guru pada semester Ganjil tahun pelajaran 2017/2018. Metode analisis data dengan menggunakan teknik analisis statistik deskriptif penskoran. Hasil penelitian menunjukkan bahwa kemampuan guru dalam menyusun perangkat penilaian afektif mengalami peningkatan dari rata-rata $68,33 \%$ pada siklus pertama menjadi rata-rata $85,38 \%$ pada siklus kedua atau mengalami peningkatan sebesar 17,05\%. Berdasarkan hasil penelitian, penggunaan teknik Office-Conference dapat meningkatkan kemampuan guru dalam Menyusun Perangkat Penilaian Afektif guru SMA Negeri 1 Pinangsori.
\end{abstract}

Kata Kunci: Kemampuan Guru, Penilaian Afektif, Supervisi Teknik Office-Conference

\section{Pendahuluan}

Kemampuan guru dalam memberhasilkan siswa tidak terlepas dari rangkaian kegiatan perencanaan, pelaksanaan, penilaian dan refleksi. Dalam Undang-Undang nomor 14 Tahun 2005 tentang Guru dan Dosen pasal 1 ayat 1 dinyatakan bahwa : "Guru adalah pendidik profesional dengan tugas utama mendidik, mengajar, membimbing, mengarahkan, melatih, menilai, dan mengevaluasi peserta didik pada pendidikan anak usia dini jalur pendidikan formal, pendidikan dasar, dan pendidikan menengah". Menurut Sagala (2011: 11-12) "Adapun tugas guru sangat banyak baik yang terkait dengan kedinasan dan profesinya di sekolah. Seperti mengajar dan membimbing para muridnya, memberikan penilaian hasil belajar peserta didik, mempersiapkan administrasi pembelajaran yang diperlukan dan kegiatan lain yang berkaitan dengan pembelajaran". 
Dengan demikian, salah satu proses yang memiliki peranan sangat penting dalam pembelajaran adalah penilaian.

Seorang guru seyogianya menguasai jenis-jenis dan teknik-teknik penilaian hasil belajar siswa. Artinya jangan hanya satu cara saja penilaian yang dilakukan. Apalagi dalam kurikulum berbasis kompetensi, memiliki keragaman aspek penilaian baik kognitif, afektif maupun psikomotor. Pada umumnya guru fokus penilaian yang dilakukan terarah pada aspek kognitif saja, sehingga orientasi penilaian berupa tes tertulis saja. Guru sebagai penilai yang harus mengumpulkan, menganalisa, menafsirkan dan akhirnya harus memberikan pertimbangan (judgement), atas tingkat keberhasilan proses pembelajaran, berdasarkan kriteria yang ditetapkan, baik mengenai aspek keefektifan prosesnya maupun kualifikasi produknya.

Dalam Permendikbud Nomor 104 Tahun 2014 tentang penilaian hasil belajar oleh pendidik pada pendidikan dasar dan pendidikan menengah, menyatakan bahwa penilaian hasil belajar oleh pendidik adalah proses pengumpulan informasitentang capaian pembelajaran peserta didik dalam kompetensi sikap spriritual dan sosial, kompetensi pengetahuan dan kompetensi ketrampilan. Pendidik menggunakan berbagai teknik penilaian, berupa test, observasi, penugasan perseorangan/kelompok dan bentuk lain yang sesuai dengan karakteristik kompotensi dan tingkat perkembangan peserta didik.

Pelaksanaan penilaian aspek afektif di lapangan mengalami kesulitan dalam mengembangkannya. Hal ini dikarenakan aspek afektif menyangkut domain yang paling dalam yang ada pada diri seseorang, yaitu kalbu atau hati nurani. Selain itu, sulitnya mengidentifikasi hasil-hasil pendidikan moral dan menerjemahkannya kedalam prilaku siswa yang diamati dan tingginya rasio antara guru dengan siswa menyebabkan sulitnya melakukan penilaian afektif. Penilaian ranah afektif sepetinya belum mendapat porsi yang lebih dibandingkan dengan penilaian ranah kognitif dan psikomotor, masih banyak para pendidik yang menilai ranah ini kurang memperhatikan rambu-rambu serta pedoman yang telah diterbitkan oleh pemerintah.

Kemampuan afektif berhubungan dengan minat dan sikap yang dapat berbentuk tanggung jawab, kerjasama, disiplin, komitmen, percaya diri, jujur, menghargai pendapat orang lain, dan kemampuan mengendalikan diri. Keberhasilan pendidik melaksanakan pembelajaran ranah afektif dan keberhasilan peserta didik mencapai kompetensi afektif perlu dinilai.

Berdasarkan hasil wawancara dan observasi terhadap guru di SMA Pinangsori kabupaten Tapanuli Tengah, yang dilaksanakan oleh peneliti, didapatkan data bahwa dalam pemberian nilai sikap siswa oleh guru ternyata tidak menggunakan instrumen yang baku, bahkan guru-guru tidak memiliki dokumen penilaian sikap siswa, sedangkan nilai sikap masing-masing siswa tertuang dalam buku Raport. Berdasarkan data ini, dapat dikatakan bahwa kemampuan guru dalam penilaian sikap siswa masih rendah. 
Ada beberapa faktor yang dapat meningkatkan kemampuan guru menyusun perangkat penilaian afektif antara lain : (1) faktor internal dan (2) faktor eksternal. Faktor internal terdiri dari : (1) niat, maksudnya bahwa niat guru berpengaruh pada peningkatan keterampilannya. Sedangkan faktor eksternal terdiri dari : (1) lingkungan; (2) kemajuan IPTEK; (3) supervisi individual; (4) supervisi kelompok.

Supervisi individual terdiri dari beberapa teknik antara lain: observasi, pertemuan individu, kunjungan antar guru, evaluasi diri, supervisi bulletin, bacaan profesional, menulis profesional, dan teknik office conference. Menurut Swearingen dalam Prasojo (2011: 106) Supervisi teknik office conference merupakan salah satu teknik pelaksanaan supervisi akademik yaitu bagian dari teknik pertemuan individual. Supervisi teknik office-conference yaitu percakapan individual yang dilaksanakan di ruang kepala sekolah atau ruang guru, di mana sudah dilengkapi dengan alat-alat bantu yang dapat digunakan untuk memberikan penjelasan pada guru. Dalam percakapan individual ini supervisor harus berusaha mengembangkan segi-segi positif guru, mendorong guru mengatasi kesulitankesulitannya, dan memberikan pengarahan, hal-hal yang masih meragukan sehingga terjadi kesepakatan konsep tentang situasi pembelajaran yang sedang dihadapi.

Berdasarkan uraian diatas, penulis melaksanakan penelitian tentang: "Peningkatan Kemampuan Guru dalam Melaksanakan Penilaian Afektif Melalui Supervisi Teknik Office-Conference di SMA
Negeri 1 Pinangsori Kabupaten Tapanuli Tengah ".

\section{Metode Penelitian}

Penelitian ini tergolong penelitian tindakan sekolah yang berlangsung selama 2 siklus. Masing-masing siklus terdiri dari tahapan perencanaan, pelaksanaan, observasi dan refleksi, dengan melibatkan guru-guru dan kepala sekolah. Penelitian dilaksanakan pada bulan Agustus September 2017, semester ganjil tahun pelajaran 2017/2018.

\section{Pembahasan dan Hasil}

Sesuai dengan tahapan pelaksanaan supervisi teknik office-conference yang telah direncanakan, maka siklus pertama dimulai dengan perencanaan dimana kepala sekolah sebagai peneliti melakukan pertemuan office-conference terhadap 13 orang guru mata pelajaran. Pada pertemuan awal dengan guru-guru, peneliti melakukan wawancara dengan mengacu pada pedoman wawancara yang telah disiapkan sebelumnya untuk mengetahui pemahaman guru-guru tentang penilaian afektif dan bagaimana penerapannya. Dari hasil wawancara terhadap keempat guru yang menjadi subjek penelitian diperoleh informasi bahwa: (1) guru telah mengetahui bahwa selain penilaian kognitif dan psikomotor, guru juga harus melakukan penilaian afektif; (2) guru belum mengetahui cara melakukan penilaian afektif; (3) penilaian afektif yang dilakukan guru selama ini tidak berpedoman pada penilaian yang menggunakan instrumen penilaian afektif; dan (4) guru setuju bahwa penilaian afektif seharusnya mengacu pada instrumen penilaian dan sepakat untuk 
membuat instrumen penilaian afektif tersebut dan melaksanakaannya. Selanjutnya dilakukan penjadwalan pertemuan officeconference terhadap masing-masing guru untuk tindakan lebih lanjut yaitu upaya untuk meningkatkan kemampuan guru menyusun perangkat penilaian afektif.

Pada tahapan pelaksanaan, peneliti melakukan beberapa kali pertemuan individual terhadap masing-masing guru dengan waktu yang berbeda sebagaimana telah dijadwalkan sebelumnya. Pertemuan office-conference ini dilakukan diruangan khusus agar pelaksanaan pertemuan dapat terjadi secara kondusif, efektif dan efisien. Dalam pertemuan ini peneliti melakukan sharing bersama guru pentingnya penilaian afektif untuk dilakukan dan membimbing guru bagaimana penyusunan perangkat penilaian afektif yang tepat dan dapat digunakan untuk menilai sikap, minat, konsep diri, nilai dan moral siswa. Pembicaraan yang dilakukan diupayakan agar tidak terlalu formal sehingga tidak muncul kesan menggurui. Guru dapat mengemukakan pendapat dan konsepnya secara bebas dan tetap diarahkan untuk menyusun perangkat penilaian dengan cara yang lebih tepat. Selanjutnya guru diberi kesempatan untuk menyusun perangkat penilaian afektif dengan tetap berpedoman pada hasil pertemuan yang dilakukan tentang penyusunan perangkat penilaian afektif.

Setelah guru menyusun perangkat penilaian afektif, peneliti menganalisis ketepatan penyusunan perangkat penilaian afektif yang dilakukan guru berdasarkan kriteria yang telah disusun sebelumnya. Ternyata dari hasil penyusunan perangkat penilaian afektif tersebut ditemukan masih terdapatnya kekurangan guru terutama dalam perumusan indikator masing-masing komponen penilaian sikap, minat, konsep diri, nilai dan moral siswa. Persentase hasil penyusunan perangkat penilaian afektif siklus pertama dan kedua

Dari analisis data didapatkan rata-rata persentase pada siklus pertama sebesar $68,33 \%$. Karena indikator keberhasilan > $80 \%$ belum tercapai, maka tindakan dilanjutkan siklus kedua.

Siklus kedua pada penelitian ini dilakukan seperti tahapan pelaksanaan penelitian pada siklus pertama yakni dimulai dengan perencanaan, pelaksanaan, observasi serta refleksi. Selanjutnya peneliti kembali melakukan analisis terhadap perangkat perangkat penilaian afektif yang telah diperbaiki oleh guru, dengan rincian hasil sebagai berikut:

Dari analisis data, didapatkan rata-rata persentase sebesar $85,38 \%$. Karena indikator keberhasilan $>80 \%$ telah tercapai, maka tindakan dihentikan pada siklus kedua.

Hasil penelitian menunjukkan bahwa kemampuan guru dalam menyusun perangkat penilaian afektif mengalami peningkatan dari rata-rata $68,33 \%$ pada siklus pertama menjadi rata-rata $85,38 \%$ pada siklus kedua atau terdapat peningkatan $17,07 \%$. 
Secara grafik peningkatan persentase hasil penyusunan perangkat penilaian afektif tersebut dapat dilihat dalam gambar 1 berikut:

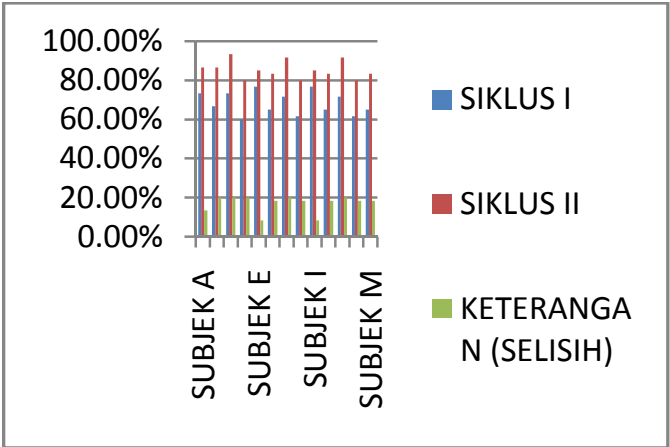

\section{Kesimpulan}

Berdasarkan hasil pelaksanaan penelitian dapat disimpulkan sebagai berikut:

1. Supervisi teknik office-conference dapat meningkatkan kemampuan guru dalam menyusun perangkat penilaian afektif di SMA Negeri 1 Pinangsori

Terjadi peningkatan persentase kemampuan guru dalam menyusun perangkat penilaian afektif dari siklus pertama rata-rata $68,33 \%$ menjadi rata-rata $85,38 \%$ pada siklus kedua atau mengalami peningkatan sebesar $17,05 \%$.

\section{Saran}

a. Hendaknya guru selalu melakukan penilaian afektif selain penilaian kognitif dan psikomotor, karena penilaian afektif mengacu pada pembentukan karakter siswa. b. Hendaknya penilaian afektif dilakukan dengan mengacu pada instrumen penilaian afektif yang dibuat oleh guru.

c. Hendaknya guru menyusun perangkat penilaian afektif yang sesuai dengan kriteria penyusunan perangkat penilaian afektif.

\section{Daftar Pustaka}

Bloom, B. S. (1976). Human characteristics and school learning. New York: McGraw-Hill Book Company.

Departemen Pendidikan Nasional. 2008. Metode dan Teknik Supervisi. Jakarta: Ditjen PMPTK. . 2008. Pengembangan Perangkat Penilaian Afektif. Jakarta: Ditjen PMPTK.

Prasojo, Lantip Diat \& Sudiyono. 2011. Supervisi Pendidikan. Yogyakarta: Penerbit Gava Media

Permendiknas Nomor 104 Tahun 2014 tentang Standar Penilaian.

Sagala, Syaiful. 2011. Kemampuan Profesional Guru dan Tenaga Kepenidikan. Bandung: Penerbit Alfabeta.

Sahertian, Piet, A. 2008. Konsep Dasar \& Teknik Supervisi Pendidikan (Dalam Rangka Membangun Sumber Daya Manusia). Jakarta: Rineka Cipta

Undang-Undang Republik Indonesia nomor 14 Tahun 2005 tentang Guru dan Dosen. 